\title{
Circadian Blood Pressure Variability in Hypertensive Patients with Coronary Heart Disease.
}

Jorge Luis León Alvarez ${ }^{1 *}$, Michel Curbelo López ${ }^{2}$, Tania Hidalgo Costa ${ }^{3}$, Miguel Ángel Yanes Quesada ${ }^{1}$, Raúl Orlando Calderín Bouza ${ }^{1}$, Andrew Sefenu Yao Dzebu ${ }^{4}$

${ }^{1}$ Doctor of Medicine. Professor in Internal Medicine. Hermanos Ameijeiras Hospital. Havana. Cuba.

${ }^{2}$ Doctor of Medicine. Specialist in Internal Medicine. Hermanos Ameijeiras Hospital. Havana. Cuba.

${ }^{3}$ Doctor of Medicine. Specialist in Biostatistics. Hermanos Ameijeiras Hospital. Havana. Cuba.

${ }^{4}$ Doctor of Medicine. Resident of Cardiology. Hermanos Ameijeiras Hospital. Havana. Cuba.

*Corresponding author: Jorge Luis León Alvarez. Hospital Ameijeiras. Address: San Lázaro 701, between Marques González and Belascoaín. Centro Habana, Habana. Cuba. ZIP: 10300. Phone: + 53-78761000. Fax: + 53-78735036.

Received date: December 18, 2019; Accepted date: December 26, 2019; Published date: January 03,2020

Citation: León Alvarez JL., Michel C. López., Tania H. Costa., Yanes Quesada MA., Calderín Bouza RO., Yao Dzebu AS. (2020) Circadian Blood

Pressure Variability in Hypertensive Patients with Coronary Heart Disease. J Clinical Cardiology and Cardiovascular Interventions, 3(2);

DOI:10.31579/2641-0419/039

Copyright: @ 2020 Jorge Luis León Alvarez. This is an open access article distributed under the Creative Commons Attribution License, which permits unrestricted use, distribution, and reproduction in any medium, provided the original work is properly cited.

\begin{abstract}
Introduction and objectives: Coronary heart disease is one of the complications of hypertension. Ambulatory blood pressure monitoring allows studying the different circadian patterns of blood pressure, but there is not enough evidence linking coronary heart disease with different circadian patterns. This research was carried out with the purpose of characterizing the circadian patterns of blood pressure in patients with essential hypertension and coronary heart disease.

Methods: Descriptive and transversal research in 68 hypertensive patients with coronary heart disease who underwent ambulatory blood pressure monitoring. The different circadian patterns of blood pressure were related to the different forms of coronary heart disease and to the control of blood pressure.

Results: In the sample, women (60.3\%) predominated over men (39.7\%). The ages were between 45 to 59 (63.3\%) and those 60 and over (36.7\%). 44.1\% did not have their blood pressure under control, 45.6\% were overweight and $38.2 \%$ were obese. The abnormal patterns were dipper $42.6 \%$, non-dipper $41.2 \%$, extreme dipper $7.4 \%$ and riser $8.8 \%$. Morning surge was observed in 29 patients (42.6\%), statistically significant in relation to the control of blood pressure ( $p=0.033)$, but not with the different types of coronary heart disease studied.

Conclusions: A statistically significant relationship was found between morning surge and control of blood pressure.

Key words: hypertension; ambulatory blood pressure monitoring; coronary heart disease; myocardial infarction; heart failure; dipper pattern; non dipper pattern; morning surge; riser
\end{abstract}

\section{Introduction}

Hypertension is a global health problem. Between 30 and $50 \%$ of the adult population in most countries suffer from hypertension. [1-3]. In Cuba, it was estimated that $30.9 \%$ of people 15 years of age or older suffer from hypertension according to the III National Survey of risk factors and preventive activities of non-communicable diseases carried out in 2010-2011 [4]. Hypertension is an important risk factor for cardiovascular and renal diseases. It's closely related to the leading causes of death in Western countries and is considered as a globally rising tracer disease, intended to control largely decreases of morbidity and mortality in the adult population $[5,6]$. Recent data shows that untreated hypertension shortens life expectancy by approximately 5 years [7]. On the other hand, more than $70 \%$ of hypertensive patients have other cardiovascular risk factors (CRF). In fact, cardiovascular complications of hypertension are more frequent in the presence of other CRF, so hypertension should be considered as another component of the Cardiovascular Risk (CR) of the subject [8].
Hypertension causes complications or injuries to target organ damage (TOD) such as brain, heart, eyes, kidney and blood vessels, which are lifethreatening if the abnormally high blood pressure (BP) figures are not corrected [9-12]. Lesions produced specifically in the heart cause left ventricular hypertrophy $(\mathrm{LVH})$, coronary heart disease and heart failure (HF) $[13,14]$. There is a close association between hypertension and coronary heart disease [15-17]. Patients with hypertension are exposed to a much higher risk of developing any type of occlusive vascular disease, including coronary heart disease. This can limit myocardial perfusion and, consequently, the oxygen supply. The demand for myocardial oxygen is increased for two reasons: first, because of the increase in the output impedance to the left ventricular ejection and, secondly, because hypertension can produce LVH. This combination of decreased oxygen supply and/or increased demand for it is particularly harmful and explains the reason why hypertensive patients are more likely than normotensive patients to suffer from angina pectoris, myocardial infarction (MI) or other coronary episodes, and are exposed to an increased risk of death from coronary heart disease [11-14]. On the other hand, atherosclerosis is the main pathophysiological and pathological basis of coronary heart disease 
and is usually the result of a set of CRF, among which hypertension stands out for its importance [17-19].

The determination of BP continues to be one of the most important clinical measures in everyday medical practice. The BP follows a circadian pattern, with higher BP levels occurring during the day and lower values at night. In many hypertensive patients, there is no nocturnal decrease in BP (non-dipper pattern). This non-dipper pattern has been associated with a worse cardiovascular prognosis [20]. Therefore, in addition to the objective of reducing BP, we should consider knowing and modifying the patient's circadian pattern of BP [21-25].

Ambulatory Blood Pressure Monitoring (ABPM) is currently a useful tool in the diagnosis and monitoring of hypertension, although it is not considered a routine technique in the study of hypertension. The ABPM shows the existence of a sleep-wake pattern, with higher BP levels during wakefulness, especially in relation to physical activities or stressful situations, and lower figures during sleep. It has been observed how BP figures during wakefulness as measured by ABPM are similar to that of BP taken in the office. There is no clear consensus regarding normal reference values for ABPM [26-29].

Alterations of the circadian pattern of BP have been associated with coronary heart disease, a higher prevalence of ventricular arrhythmias and a high morbidity and mortality due to cardiovascular diseases; even in the accentuated dipper pattern, coronary heart disease can occur due to organ perfusion disorders, which may not only be a mechanism of vascular injury, but also a condition associated in patients with a worse prognosis. Therefore, the conversion of circadian patterns that are related to a higher $\mathrm{CR}$ according to the physiological circadian pattern is of vital importance and therefore constitutes an objective in the therapy of patient's with hypertension and provides an adequate decrease in night averages obtained in relation to the averages achieved during the diurnal cycle $[29,30]$.

There is strong evidence that a persistent pattern of the absence of nocturnal descent is associated with a more pronounced cardiac involvement [31]. Several studies have consistently verified that MI has a higher prevalence between 6 am and 12 noon, than at other times during the day or night [32-35] .Data from prospective and population-based clinical studies show that ambulatory BP predicts the risk of cardiovascular events after adjustment in relation to conventional BP (assessed in the office) [36]. A classic prospective study, carried out by Perloff et al [37]. established that the CR was higher in patients with higher values of ambulatory daytime BP than in those in which they were lower, independent of the levels of the BP measured in office. It has been found that outpatient BP is superior in predicting adverse cardiovascular clinical events when compared to conventional office BP measurements. In two studies, the prognostic value of ambulatory BP in the general population was considered $[38,39]$. In both studies, after the adjustment for sex, age, smoking habit, initial office BP and antihypertensive treatment, ambulatory BP proved to be a better predictor of cardiovascular death than office BP [14-40]. On the other hand, nocturnal BP and ambulatory SBP were the best predictors of cardiovascular death. Similar results were also observed in the Dublin Outcome Study, carried out among 5,000 patients for 5 years [41]. However, the relationship between the coronary heart disease and the different circadian patterns of BP is not yet fully understood. In addition, the current accepted BP figures for the dipper status would not necessarily have to represent a normal nocturnal circadian profile [32-42]. Despite the accumulated evidence, the relationship between the presence of coronary heart disease in the hypertensive patient and the various circadian patterns of $\mathrm{BP}$, in relation to the type of coronary heart disease and the control of the SP remains uncertain [43-47]. Motivated by characterizing in essential hypertensive patients with coronary heart disease how the different circadian patterns of BP behave in relation to the control of their BP and the type of coronary heart disease is why we conducted this research at "Hermanos Ameijeiras" Hospital.

\section{Materials and Methods}

A cross-sectional descriptive investigation was carried out between October 1, 2017 and September 30, 2018 at "Hermanos Ameijeiras" Hospital located in Havana, Cuba. The sample consisted of 68 patients of both sexes, 18 years old and older, who were attended in the hospital's hypertension offices, with the characteristic of being patients with essential hypertension, previously diagnosed with coronary heart disease, being treated or not, with typical or atypical symptoms of coronary disease, with diagnostic coronary angiography of coronary heart disease performed prior to the investigation. The following clinical forms coronary heart disease were considered: myocardial infarction (more than 3 months since it's appearance), chronic stable angina pectoris, recovered sudden cardiac arrest and other forms of presentation of coronary heart disease: heart failure, arrhythmias and conduction disorders. Patients with diabetes mellitus or with other endocrinopathies, with severe acute or chronic diseases, pregnant women and patients with malformations that prevented the measurement of BP were excluded.

For all patients, following the acquisition of informed consent, the following data were collected by anamnesis: age, sex and BP, and were recorded on the data collection form (it was considered controlled if SBP/DSP $<140 / 90$ and uncontrolled if SBP/DBP $\geq 140 / 90$ ) and body mass index (BMI) per the Quetelet formula [48].

In addition, ABPM was performed using the HIPERMAX equipment according to the hospital protocol and was classified as dipper, non-dipper, extreme dipper, riser, morning surge and nocturnal hypertension [49-54].

\section{Statistical Analysis}

The information obtained was fed into a digital database and statistical processing was performed with the SPSS program version 20.0 (SPSS, Inc.; Chicago, Illinois, United States). Summary measures were used according to the type of variable that was analyzed. For the variable age: mean, standard deviation, minimum value and maximum value were calculated. For the variables sex, type of coronary heart disease, BMI and circadian patterns of BP: absolute numbers and percentages were calculated. For the search for association between the circadian patterns of BP with respect to $\mathrm{BP}$ control and the type of coronary heart disease, the Pearson Square Chi test $\left(\mathrm{X}^{2}\right)$ or Fisher's exact test was performed on $2 \times 2$ tables that had presented $20 \%$ or more of the cells with absolute numbers with values less than or equal to 5 . In all the hypothesis tests a level of significance was set $\alpha=0.05$. The information was presented in statistical tables made using Microsoft Word text editor for Windows 10.

\section{Results}

Table 1 shows the behavior of the different clinical variables in the patients studied $(n=68) .60 .3 \%$ were females and $39.7 \%$ were males. 


\begin{tabular}{|c|c|c|c|}
\hline \multicolumn{2}{|c|}{$\begin{array}{l}\text { Variables } \\
(n=68)\end{array}$} & No. & $\%$ \\
\hline \multirow{2}{*}{ Sex } & Female & 41 & 60,3 \\
\hline & Male & 27 & 39,7 \\
\hline \multirow{3}{*}{ Age } & 18-44 years & 0 & 0 \\
\hline & $45-59$ years & 43 & 63,3 \\
\hline & 60 or more years & 25 & 36,7 \\
\hline \multirow{2}{*}{ Control of blood pressure } & Uncontrolled & 30 & 44,1 \\
\hline & Controlled & 38 & 55,9 \\
\hline \multirow{3}{*}{ Body mass index } & Normal & 11 & 16,2 \\
\hline & Overweight & 31 & 45,6 \\
\hline & Obesity & 26 & 38,2 \\
\hline \multirow{3}{*}{$\begin{array}{l}\text { Type of coronary heart dis- } \\
\text { ease }\end{array}$} & Angina pectoris & 42 & 61,8 \\
\hline & Myocardial infarction & 10 & 14,7 \\
\hline & Heart failure & 16 & 23,5 \\
\hline \multirow{6}{*}{$\begin{array}{l}\text { Circadian patterns of blood pres- } \\
\text { sure }\end{array}$} & Dipper & 29 & 42,6 \\
\hline & Non dipper & 28 & 41,2 \\
\hline & Extreme dipper & 5 & 7,4 \\
\hline & Riser & 6 & 8,8 \\
\hline & Morning surge & 29 & 42,6 \\
\hline & Nocturnal hypertension & 0 & 0 \\
\hline
\end{tabular}

Table 1: Behavior of clinical variables and distribution of circadian patterns of blood pressure.

All the patients studied were over 45 years old, $63.3 \%$ being predominantly between 45 and 59 years old. Regarding BP control, 55.9\% were controlled and $44.1 \%$ were not. Overweight and obesity were very striking characteristics in our patients, with $45.6 \%$ and $38.2 \%$ respectively. In addition, we observed the distribution of the different types of heart disease found in our patients, with angina pectoris being the most frequent with $61.8 \%$, followed by heart failure with $23.5 \%$ and MI with $147 \%$. Additionally, we observed the distribution of the different circadian BP patterns found in the patients studied. The dipper pattern considered the physiological pattern was present in $42.6 \%$. According to the abnormal patterns (non-dipper, extreme dipper and riser) we highlight that $41.2 \%$ had a non-dipper pattern, among patients with an abnormal circadian pattern of BP $(n=39)$. We found that $42.6 \%$ had a morning surge pattern and we did not find patients with nocturnal hypertension.

Table 2 reveals the relationship between the different circadian patterns of BP and the control of BP. Although the dipper pattern predominated in patients with BP control with $47.4 \%$ and the non-dipper pattern in the uncontrolled patients with $43.3 \%$, this difference was not statistically significant.

\begin{tabular}{|c|c|c|c|c|c|c|c|}
\hline \multirow{3}{*}{$\begin{array}{c}\text { Circadian patterns of blood } \\
\text { pressure }\end{array}$} & \multicolumn{4}{|c|}{ Control of blood pressure } & \multirow{2}{*}{\multicolumn{2}{|c|}{$\begin{array}{c}\text { Total } \\
(\mathrm{N}=68)\end{array}$}} & \multirow{3}{*}{$\mathbf{p}$} \\
\hline & \multicolumn{2}{|c|}{$\begin{array}{c}\text { Yes } \\
(n=38)\end{array}$} & \multicolumn{2}{|c|}{$\begin{array}{c}\text { No } \\
(n=30)\end{array}$} & & & \\
\hline & No & $\%$ & No & $\%$ & No & $\%$ & \\
\hline Dipper & 18 & 47,4 & 11 & 36,7 & 29 & 42,6 & 0,376 ** \\
\hline Non dipper & 15 & 39,5 & 13 & 43,3 & 28 & 41,2 & $0,470 * *$ \\
\hline Extreme dipper & 3 & 7,9 & 2 & 6,7 & 5 & 7,4 & $0,613^{*}$ \\
\hline Riser & 2 & 5,3 & 4 & 13,3 & 6 & 8,8 & $0,231^{*}$ \\
\hline Morning surge & 12 & 31,6 & 17 & 56,7 & 29 & 42,6 & $0,033 * *$ \\
\hline
\end{tabular}

Table 2: Relationship between circadian patterns of blood pressure and blood pressure control.

In the morning surge pattern found in 29 patients who had an abnormal circadian pattern of BP, $56.7 \%$ had no BP control and this was a statistically significant difference $(\mathrm{p}=0.033)$.
Table 3 shows the relationship between the different circadian patterns of $\mathrm{BP}$ and the morning surge pattern, observing that there was no statistically significant relationship with any of the circadian patterns, although we found it more frequent in the non-dipper pattern with $41.4 \%$. 


\begin{tabular}{|c|c|c|c|c|c|c|c|}
\hline \multirow{3}{*}{$\begin{array}{c}\text { Circadian patterns of blood } \\
\text { pressure }\end{array}$} & \multicolumn{4}{|c|}{ Morning surge pattern } & & & \multirow{3}{*}{$\mathbf{p}$} \\
\hline & \multicolumn{2}{|c|}{$\begin{array}{c}\text { Yes } \\
(n=29)\end{array}$} & \multicolumn{2}{|c|}{$\begin{array}{c}\text { No } \\
(n=39)\end{array}$} & \multicolumn{2}{|c|}{$\begin{array}{c}\text { Total } \\
(\mathrm{N}=68)\end{array}$} & \\
\hline & No & $\%$ & No & $\%$ & No & $\%$ & \\
\hline Dipper & 11 & 37,9 & 18 & 46,2 & 29 & 42,6 & $0,498 * *$ \\
\hline Non dipper & 12 & 41,4 & 16 & 41,0 & 28 & 41,2 & $0,977 * *$ \\
\hline Extreme dipper & 2 & 6,9 & 3 & 7,7 & 5 & 7,4 & $0,640^{*}$ \\
\hline Riser & 4 & 13,8 & 2 & 5,1 & 6 & 8,8 & $0,207 *$ \\
\hline
\end{tabular}

Table 3: Relationship between circadian patterns of blood pressure and the morning surge pattern.

Table 4 shows the relationship between the different circadian patterns of $\mathrm{BP}$ and patients with chronic stable angina pectoris showing $47.6 \%$ who had a non-dipper pattern. In addition, the morning surge pattern was pre sent in $40.5 \%$, although both results had no significant difference. This table highlights that the dipper pattern independently, whether or not angina pectoris was present showed significant results of $42.6 \%(p=0.048)$.

\begin{tabular}{|c|c|c|c|c|c|c|c|}
\hline \multirow{3}{*}{$\begin{array}{c}\text { Circadian patterns of blood } \\
\text { pressure }\end{array}$} & \multicolumn{4}{|c|}{ Angina pectoris } & \multirow{2}{*}{\multicolumn{2}{|c|}{$\begin{array}{c}\text { Total } \\
(\mathrm{N}=68)\end{array}$}} & \multirow{3}{*}{$\mathbf{p}$} \\
\hline & \multicolumn{2}{|c|}{$\begin{array}{c}\text { Yes } \\
(n=42)\end{array}$} & \multicolumn{2}{|c|}{$\begin{array}{c}\text { No } \\
(n=26)\end{array}$} & & & \\
\hline & No & $\%$ & No & $\%$ & No & $\%$ & \\
\hline Dipper & 14 & 33,3 & 15 & 57,7 & 29 & 42,6 & $0,048 * *$ \\
\hline Non dipper & 20 & 47,6 & 8 & 30,8 & 28 & 41,2 & $0,170 * *$ \\
\hline Extreme dipper & 4 & 9,5 & 1 & 3,8 & 5 & 7,4 & $0,361 *$ \\
\hline Riser & 4 & 9,5 & 2 & 7,7 & 6 & 8,8 & $0,582 *$ \\
\hline Morning surge & 17 & 40,5 & 12 & 46,2 & 29 & 42,6 & $0,645^{* *}$ \\
\hline
\end{tabular}

Table 4: Relationship between circadian patterns of blood pressure and chronic stable angina pectoris

Table 5 shows the relationship between the different circadian patterns of BP and the presence of MI $(n=10)$. 70\% were classified as dipper but they also had a morning surge pattern.

\begin{tabular}{|c|c|c|c|c|c|c|c|}
\hline \multirow{3}{*}{$\begin{array}{c}\text { Circadian patterns of blood } \\
\text { pressure }\end{array}$} & \multicolumn{4}{|c|}{ Myocardial infarction } & & & \multirow{3}{*}{$\mathbf{p}$} \\
\hline & \multicolumn{2}{|c|}{$\begin{array}{c}\text { Yes } \\
(n=10)\end{array}$} & \multicolumn{2}{|c|}{$\begin{array}{c}\text { No } \\
(n=58)\end{array}$} & \multicolumn{2}{|c|}{$\begin{array}{c}\text { Total } \\
(\mathrm{N}=68)\end{array}$} & \\
\hline & No & $\%$ & No & $\%$ & No & $\%$ & \\
\hline Dipper & 7 & 70,0 & 22 & 37,9 & 29 & 42,6 & $0,061 *$ \\
\hline Non dipper & 2 & 20,0 & 26 & 44,8 & 28 & 41,2 & $0,129 *$ \\
\hline Extreme dipper & 0 & 0,0 & 5 & 8,6 & 5 & 7,4 & $0,440 *$ \\
\hline Riser & 1 & 10,0 & 5 & 8,6 & 6 & 8,8 & $0,630 *$ \\
\hline Morning surge & 7 & 70,0 & 22 & 37,9 & 29 & 42,6 & $0,061^{*}$ \\
\hline
\end{tabular}

Table 5: Relationship between circadian patterns of blood pressure and the presence of myocardial infarction.

Table 6 shows the relationship between BPP circadian patterns and the presence of heart failure $(\mathrm{n}=16)$.

Both dipper and non-dipper patterns showed the same results with $43.5 \%$ and the morning surge pattern was $37.5 \%$ although without statistical significance.

\begin{tabular}{|c|c|c|c|c|c|c|c|}
\hline \multirow{3}{*}{$\begin{array}{c}\text { Circadian patterns of blood } \\
\text { pressure }\end{array}$} & \multicolumn{4}{|c|}{ Heart failure } & & & \multirow{3}{*}{$\mathbf{p}$} \\
\hline & \multicolumn{2}{|c|}{$\begin{array}{c}\text { Yes } \\
(n=16)\end{array}$} & \multicolumn{2}{|c|}{$\begin{array}{c}\text { No } \\
(n=52)\end{array}$} & \multicolumn{2}{|c|}{$\begin{array}{c}\text { Total } \\
(\mathrm{N}=68)\end{array}$} & \\
\hline & No & $\%$ & No & $\%$ & No & $\%$ & \\
\hline Dipper & 7 & 43,8 & 22 & 42,3 & 29 & 42,6 & $0,919 * *$ \\
\hline Non dipper & 7 & 43,8 & 21 & 40,4 & 28 & 41,2 & $0,811 * *$ \\
\hline Extreme dipper & 1 & 6,2 & 4 & 7,7 & 5 & 7,4 & $0,665^{*}$ \\
\hline Riser & 1 & 6,2 & 5 & 9,6 & 6 & 8,8 & $0,566^{*}$ \\
\hline Morning surge & 6 & 37,5 & 23 & 44,2 & 29 & 42,6 & $0,634 * *$ \\
\hline
\end{tabular}

Table 6: Relationship between circadian patterns of blood pressure and heart failure.

Discussion

Knowledge about hypertension has been increased by the contribution of
ABPM [55-58]. Thus, for example, the concept of BP variability and its importance as a predictor of morbidity and TOD have been conclusively established [51-53]. The results obtained in this work are valid for this 
sample and are not intended to be extrapolated to other populations. ABPM has introduced a considerable change in the diagnosis and treatment of hypertension, shifting the interest from random measurement of $\mathrm{BP}$ to the BP that patients present in their usual environment. This has allowed us to avoid the phenomenon of white coat hypertension, confirm the diagnosis of hypertension, detect masked hypertension, assess the response to treatment and study the variability, etc [54-60].

One of the aspects that has required more attention in recent years has been the assessment of the circadian pattern of BP in sleep-wake cycles. Thus, some studies have shown that the absence of nocturnal decrease in $\mathrm{BP}$ is associated with a worse cardiovascular prognosis and TOD, both in hypertensive patients and in the general population, and it has been shown that the decrease in nighttime SBP is associated with a lower risk of cardiovascular events compared to subjects who do not experience such physiological decline [61-64]. It is known that there is an inverse correlation of BP in sleep and cardiovascular events in relation to the prognosis linked to this variable, which normal value is a reduction between 10 to $20 \%$ of BP during sleep in relation to wakefulness, even in the presence of normal average BP values obtained by ABPM [40, 42, 65, 66].

In this sample the difference in the distribution by sex of the patients was not significant, if we had a predominance in the ages above 45 years. Which think is because hypertension in its natural course during many years has little clinical expression and the appearance of TOD such as LVH in these patients is an expression of structural changes at the level of the vascular endothelium and the heart, which takes years to establish. A high frequency of uncontrolled BP was found (44.1\%), which we consider to be one of the most important factors that favors the onset of TOD and in specific coronary heart disease.

The results of this research showed a circadian profile in $57.4 \%$ of the studied subjects that did not show an adequate reduction in BP at night or at rest. These results are related to those reported by other authors [51, 52, 53] .

Multiple pathophysiological abnormalities in essential hypertension could explain the abnormal pattern of BP decrease during sleep associated with coronary heart disease, since it is considered that the non-decrease of nocturnal decrease in BP is a consequence of alterations in the activation of the sympathetic nervous system, stimulation of the renin angiotensin system, insulin resistance and induction of the proliferation of smooth muscle cells in the blood vessels, which can cause alterations in the structure and function of the arteries. This occurs by several mechanisms. Firstly, insulin stimulates the production of nitric oxide by the endothelial cell producing a decrease in peripheral vascular resistance and a decrease in BP. It also inhibits the formation of migration-dependent lesions and the proliferation of vascular smooth muscles and decreases vasoconstriction mediated by the sympathetic nervous system. For this reason, an increase in resistance to insulin uptake by the endothelial cell has an inverse effect on these vasomodulatory mechanisms while the resulting hyperinsulinemia increases the vasoconstrictor vascular response by stimulating the sympathetic nervous system. This hyperinsulinemia could explain the adequate non-decrease in BP during sleep, highlighting the nondipper and reverse dipper effect in these patients [66-70]. Another very important factor is the activation or inhibition of the anti-aging gene related with the different circadian patterns of BP and the coronary heart disease [71-73].

Recently, known dipper and non-dipper patterns have given attention to two additional behaviors that may coexist with abnormal circadian patterns such as nocturnal hypertension and morning surge conditions that have been described in a varied spectrum of situations that include sleep apnea and TOD [74]. and more importantly the increased risk of fatal and non-fatal cardiovascular events ${ }^{75}$ and their proven occurrence in the first hours of waking and during the day $[76,77]$. On the other hand, the relationship between coronary heart disease and the different circadian patterns of abnormal BP is strongly demonstrated $[78,79]$. but not with the morning surge nor with nocturnal hypertension, which have been considered by several researchers as different expressions of the same phenomenon of morning surge [80]. These alterations could be explained because during the first hours of the morning, physiological alterations take place, such as an increase in BP, platelet aggregation, secretion of catecholamine, cortisol, activation of the renin angiotensin system and other hormones $[81,82]$. The morning accentuation of these physiological processes, acting on a vulnerable plaque of atheroma can alone or together, contribute to the higher incidence of cardiovascular disease during this time [83]. There are several studies that have consistently verified that MI has a higher prevalence between 6 am and 12 noon than at other times of the day or night [84]. In addition, the incidence of subarachnoid hemorrhage [85]. ischemic cerebrovascular disease [86]. hemorrhagic cerebrovascular disease [87]. And transient ischemic attacks [88]. Is higher in the morning after waking up [89].

The clinical implications of recognizing a circadian cycle of presentation of cardiovascular disease are reflected in the importance that can be given to pharmacological interventions for better protection at times of increased risk. Perhaps, long-term medications administered at night or that do not lose their action by morning, are of clinical utility $[90,91]$.

There are reports that MI occurs 2 to 3 times more frequently in the morning than at night $[91,92]$. In the early hours of the morning, an increase in BP and heart rate results in an increase in the demand for oxygen and energy by the heart, while the vascular tone of the coronary arteries increases, resulting in a decrease in coronary blood flow and oxygen supply. This inconsistency between supply and demand causes the high frequency of MI onset in the morning [93-94]. Other factors are also involved favoring hypercoagulability, such as plasminogen activator inhibitor 1 and platelet surface activators such as P-selectin [95].

In a longitudinal cohort, the Ohasama Study [96] conducted in Japan in which BP was measured every morning, showed that morning BP levels predict cardiovascular death events more accurately than that obtained randomly in that same population. This same cohort was analyzed after 10 years of follow-up, with 1,352 patients (872 women and 460 men), ages over 40 years could be followed, demonstrating that the values of nocturnal BP exceeded daytime BP in the prediction of cardiovascular mortality [97].

Verdecchia et al [98]. studied the relationship between daytime and nighttime BP and BP figures at dawn in a cohort of 3012 patients with essential untreated hypertension and followed them for 8.44 years, of which 268 developed a major cardiovascular event (heart failure, MI or cardiovascular death). They applied the Cox model after adjusting predictive covariates such as age, sex, diabetes, smoking, total cholesterol, LVH and glomerular filtration and observed that the morning surge pattern is an independent predictor of cardiovascular events.

Li et al [99]., studied the prognostic significance of the morning surge pattern using the "International Database on Ambulatory Blood Pressure in Relation to Cardiovascular Outcome", analyzed 5645 randomly selected patients in 8 countries with an average follow-up period of 11.4 years and concluded that the morning surge pattern independently and significantly predicted cardiovascular events (heart failure, MI or cardiovascular death), suggesting its probable role in stratification of $\mathrm{CR}$ through ABPM.

Other researchers have downplayed these findings. Cuspidi et al [100] in an investigation conducted in 343 patients with TOD to evaluate the pattern of nocturnal hypertension between dipper and non-dipper patients did 
not find significant differences between these two patterns and the presence or absence of nocturnal hypertension regardless of the TOD they had.

The control of BP is one of the essential therapeutic objectives to reduce cardiovascular risk and cardiovascular morbidity and mortality. In our investigation, it was evident that a considerable number of patients (44.1\%) at the time of the study had high BP levels, although the random measurement of BP in the office is not a faithful indicator of the true behavior of BP in patients, due to the existence of various factors among which are the white coat hypertension and others, considering that this is an essential factor in the development of TOD and especially coronary heart disease.

\section{Limitations}

We are aware of the limitations of our study since several factors, some difficult to control, such as physical activity, sleep quality, the prevalence of sleep apnea and the use of fixed periods have not been taken into account for the daytime-nighttime period, the lack of reproducibility that the night/daytime ratio implies, or the phenomenon of "mean regression" when the BP determinations are repeated. On the other hand, some research affirms that the study of patients based solely on an exam is not reliable. The conclusions of the study should be interpreted as hypothesis generators and should be confirmed in future studies with longer followup.

\section{Conclusions}

In summary, this study shows a very high percentage of hypertensive patients with abnormal circadian BP patterns (non-dipper, riser and extreme dipper) without having statistical significance in the study. The morning surge pattern in relation to the BP control showed values with statistical significance with respect to the rest of the patterns studied, but not with the different types of coronary heart disease. These results suggest the convenience of performing ABPM in order to identify patients with these patterns. Since in clinical practice it is impossible to perform this technique on all hypertensive patients due the lack of access to it, perhaps patients with TOD and especially those with coronary heart disease would benefit more.

Potential conflict of interest: The authors have declared that no competing interests exist.

Sources of funding: This study did not have external sources of funding.

\section{References}

1. Lawes CM, Vander Hoorn S, Rodgers A. (2008) International Society of $\mathrm{H}$. global burden of blood pressure-related disease, Lancet. 3; 371(9623):1513-1518.

2. Lloyd-Jones DM, Evans JC, Levy D. (2005) Hypertension in adults across the age spectrum: current outcomes and control in the community. JAMA. 27;294(4):466-472.

3. Whelton PK, Carey RM, Aronow WS, Casey DE Jr, Collins KJ, Dennison Himmelfarb C. et al. (2018) 2017

4. ACC/AHA/AAPA/ABC/ACPM/AGS/APhA/ASH/ASPC/NMA/PC NA Guideline for the Prevention, Detection, Evaluation, and Man- agement of High Blood Pressure in Adults: A Report of the American College of Cardiology/American Heart Association Task Force on Clinical Practice Guidelines. Circulation. 23;138(17):e484-e594.

5. Bonet Gorbea M, Varona Pérez P. (2014) III Encuesta nacional de factores de riesgo y actividades preventivas de enfermedades no trasmisibles. Cuba 2010-2011. Editorial Ciencias Médicas.

6. Rapsomaniki E, Timmis A, George J, Pujades-Rodriguez M, Shah $\mathrm{AD}$, Denaxas S, et al. Blood pressure and incidence of twelve cardiovascular diseases: lifetime risks, healthy life-years lost, and agespecific associations in $1 \cdot 25$ million people. Lancet. 2014 May 31;383(9932):1899-1911.

7. Forounfazar MH, Liu P, Roth GA, Ng M, Biryukov S, Marczak L, et al. Global burden of hypertension and systolic blood pressure of at least 110 to $115 \mathrm{~mm} \mathrm{Hg}, 1990-2015$. JAMA. 2017 Jan 10;317(2):165-182.

8. Alcocer L, Chagas A. (2009) High blood pressure in Latin America: a call to action. Ther Adv Cardiovasc Dis. Aug;3(4):259-285.

9. Whitworth JA. (2003) World Health Organization, International Society of Hypertension Writing Group. 2003 World Health Organization (WHO)/International Society of Hypertension (ISH) statement on management of hypertension. J Hypertens. Nov;21(11):19831992.

10. Rosendorff C, Lackland DT, Allison M, Aronow WS, Black HR, Blumenthal RS, et al. (2015) Treatment of hypertension in patients with coronary artery disease: a scientific statement from the American Heart Association, American College of Cardiology, and American Society of Hypertension. Circulation. May 12;131(19): e435470.

11. Lazzeroni D, Rimoldi O, Camici PG. From Left Ventricular Hypertrophy to Dysfunction and Failure. Circ J. 2016;80(3):555-564.

12. Berk BC, Fujiwara K, Lehoux S. ECM remodeling in hypertensive heart disease. J Clin Invest. 2007 Mar;117(3):568-575.

13. Vidal-Petiot E, Ford I, Greenlaw N, Ferrari R, Fox KM, Tardif JC, et al. (2016) Cardiovascular event rates and mortality according to achieved systolic and diastolic blood pressure in patients with stable coronary artery disease: an international cohort study. Lancet. Oct 29;388(10056):2142-2152. Natural Course of Isolated Pulmonary Valve Stenosis in Infants and Children Utilizing Doppler Echocardiography

14. Williams B, Mancia G, Spiering W, Agabiti Rosei E, Azizi M, Burnier M, et al. (2018)ESC/ESH Guidelines for the management of arterial hypertension. J Hypertens. 2018 Oct;36(10):1953-2041.

15. Frohlich ED, Apstein C, Chobanian AV, Devereux RB, Dustan HP, Dzau V et al. (1992) The heart in hypertension. N Engl J Med. Oct 1;327(14):998-1008.

16. Izzo JL Jr, Gradman AH. (2004) Mechanisms and management of hypertensive heart disease: from left ventricular hypertrophy to heart failure. Med Clin North Am. Sep;88(5):1257-1271.

17. González A, Ravassa S, López B, Moreno MU, Beaumont J, San José G, et al. Myocardial Remodeling in Hypertension. Toward a New View of Hypertensive Heart Disease. Hypertension. 2018 Sep;72(3):549-558.

18. Lazzeroni D, Rimoldi O, Camici PG. (2016) From Left Ventricular Hypertrophy to Dysfunction and Failure. Circ J. 80(3):555-564.

19. Schmieder RE. (2005) The role of non-haemodynamic factors of the genesis of LVH. Nephrol Dial Transplant. Dec;20(12):2610-2612.

20. Goldstein DS. Plasma norepinephrine during stress in essential hypertension. Hypertension. 1981 Sep-Oct;3(5):551-556.

21. Olesen TB, Stidsen JV, Blicher MK, Pareek M, Rasmussen S, Vishram-Nielsen JKK, et al. (2017) Impact of Age and Target-Organ 
Damage on Prognostic Value of 24-Hour Ambulatory Blood Pressure. Hypertension. Nov;70(5):1034-1041.

22. Agarwal R, Bills JE, Hecht TJ, Light RP. (2011) Role of home blood pressure monitoring in overcoming therapeutic inertia and improving hypertension control: a systematic review and meta-analysis. Hypertension. Jan;57(1):29-38.

23. Asayama K, Ohkubo T, Kikuya M, Obara T, Metoki H, Inoue R, et al. (2006) Prediction of stroke by home "morning" versus "evening" blood pressure values: the Ohasama study. Hypertension. Oct;48(4):737-743.

24. Pierdomenico SD, Pierdomenico AM, Cuccurullo F. (2014) Morning blood pressure surge, dipping, and risk of ischemic stroke in elderly patients treated for hypertension. Am $\mathrm{J}$ Hypertens. Apr;27(4):564-570.

25. Pierdomenico SD, Pierdomenico AM, Di Tommaso R, Coccina F, Di Carlo S, Porreca E, et al. (2016) Morning blood pressure surge, dipping, and risk of coronary events in elderly treated hypertensive patients. Am J Hypertens. Jan;29(1):39-45.

26. Boggia J, Li Y, Thijs L, Hansen TW, Kikuya M, Björklund-Bodegård K, et al. (2007) International Database on Ambulatory Blood Pressure Monitoring in Relation to Cardiovascular Outcomes (IDACO) Investigators. Prognostic accuracy of day versus night ambulatory blood pressure: a cohort study. Lancet. Oct 6;370(9594):1219-1229.

27. Sega R, Facchetti R, Bombelli M, Cesana G, Corrao G, et al ( 2005). Prognostic value of ambulatory and home blood pressures compared with office blood pressure in the general population: follow-up results from the Pressioni Arteriose Monitorate e Loro Associazioni(PAMELA) study. Circulation.12;111(14):1777-17778

28. Kollias A, Andreadis E, Agaliotis G, Kolyvas GN, Achimastos Aet al (2018). The optimal night time home blood pressure monitoring schedule: agreement with ambulatory blood pressure and association with organ damage. J Hypertens. 36(2):243-249.

29. Salles GF, Reboldi G, Fagard RH, Cardoso CR, Pierdomenico SD, et al. (2016) Prognostic effect of the nocturnal blood pressure fall in hypertensive patients: The Ambulatory Blood Pressure Collaboration in patients with Hypertension (ABC-H) meta-analysis. Hypertension. 67(4):693-700.

30. ABC-H Investigators, Roush GC, Fagard RH, Salles GF, Pierdomenico SD et al. (2014) Prognostic impact from clinic, daytime, and night-time systolic blood pressure in nine cohorts of 13,844 patients with hypertension. J Hypertens. 32(12):2332-40.

31. Karmali KN, Lloyd-Jones DM, van der Leeuw J, Goff DC, Jr., Yusuf Set al. ( 2018) Blood pressure-lowering treatment strategies based on cardiovascular risk versus blood pressure: A meta-analysis of individual participant data. PLoS Med. 20;15(3):e1002538.

32. Cheng HM, Wu CL, Sung SH, Lee JC, Kario Ket al. (2017) Prognostic Utility of Morning Blood Pressure Surge for 20-Year All Cause and Cardiovascular Mortalities: Results of a Community-Based Study. J Am Heart Assoc. 9;6(12).

33. Gorostidi M, Sobrino J, Segura J, Sierra C, de la Sierra A, et al. ( 2007) Ambulatory blood pressure monitoring in hypertensive patients with high cardiovascular risk: a cross-sectional analysis of a 20,000-patient database in Spain. J Hypertens. 25(5):977-984.

34. Verdecchia P, Angeli F, Borgioni C, Gattobigio R, Reboldi G (2007) Ambulatory blood pressure and cardiovascular outcome in relation to perceived sleep deprivation. Hypertension. 49(4):777-783.

35. Fagard RH, Thijs L, Staessen JA, Clement DL, De Buyzere ML, (2009) Night-day blood pressure ratio and dipping pattern as predictors of death and cardiovascular events in hypertension. J Hum Hypertens. 23(10):645-653.
36. Eguchi K, Hoshide S, Ishikawa J, Pickering TG, Schwartz JE et al. (2009) Nocturnal nondipping of heart rate predicts cardiovascular events in hypertensive patients. J Hypertens. 27(11):2265-70.

37. De la Sierra A, Redon J, Banegas JR, Segura J, Parati G, et al (2009) Prevalence and factors associated with circadian blood pressure patterns in hypertensive patients. Hypertension. 53(3):466-72.

38. Perloff D, Sokolow M, Cowan R (1991) The prognostic value of ambulatory blood pressure. J Hypertens Suppl. 9(1): S33-9; discussion S39-40.

39. Wroe SJ, Sandercock P, Bamford J, Dennis M, Slattery Jet al (1992) Diurnal variation in incidence of stroke: Oxfordshire community stroke project. BMJ. 18;304(6820):155-157.

40. Kario K, Pickering TG, Umeda Y, Hoshide S, Hoshide Y, et al (2003) Morning surge in blood pressure as a predictor of silent and clinical cerebrovascular disease in elderly hypertensives: a prospective study. Circulation. 18;107(10):1401-1406.

41. Imai Y, Ohkubo T, Sakuma M, Tsuji I I, Satoh H, et al (1996) Predictive power of screening blood pressure, ambulatory blood pressure and blood pressure measured at home for overall and cardiovascular mortality: a prospective observation in a cohort from Ohasama, northern Japan. Blood Press Monit. 1(3):251-254.

42. Dolan E, Stanton A, Thijs L, Hinedi K, Atkins N et al (2005) Superiority of ambulatory over clinic blood pressure measurement in predicting mortality: the Dublin outcome study. Hypertension. 46(1):156-161.

43. Cuspidi C, Sala C, Valerio C, Negri F, Mancia G (2012)Nocturnal Hypertension and Organ Damage in Dippers and Nondippers. Am J Hypertens. 25(8):869-875.

44. Verdecchia P, Angeli F, Mazzotta G, Garofoli M, Ramundo E, et al (2012) Day-night dip and early-morning surge in blood pressure in hypertension: prognostic implications. Hypertension. 60(1):34-42.

45. De la Sierra A, Banegas JR, Segura J, Gorostidi M, Ruilope LM (2012)CARDIORISC Event Investigators. Ambulatory blood pressure monitoring and development of cardiovascular events in highrisk patients included in the Spanish ABPM registry: the CARDIORISC Event study. J Hypertens. 30(4):713-719.

46. Leoncini G, Viazzi F, Storace G, Deferrari G, Pontremoli R (2013) Blood pressure variability and multiple organ damage in primary hypertension. J Hum Hypertens. 27(11):663-670.

47. Hermida RC, Ayala DE, Mojón A, Fernández JR (2011) Decreasing sleep-time blood pressure determined by ambulatory monitoring reduces cardiovascular risk. J Am Coll Cardiol. 6;58(11):1165-1173.

48. Vishram JK, Borglykke A, Andreasen AH, Jeppesen J, Ibsen $\mathrm{H}$ et al (2014) Do other cardiovascular risk factors influence the impact of age on the association between blood pressure and mortality? The MORGAM project. J Hypertens. 32(5):1025-1032.

49. Pérez Caballero MD, León Alvarez JL, Dueñas Herrera A, Alfonzo Guerra JP (2018) Navarro Despaigne DA, De la Noval García R, et al. Hipertensión arterial. Guía para el diagnóstico, evaluación y tratamiento. ISBN 978-959-313-643-643.

50. Manual de Prácticas Médicas (2012) H.C.Q. "Hermanos Ameijeiras" IV Edición. Editores científicos: Héctor Rodríguez Silva, José Antonio Negrin Villavicencio (Ed), La Habana: Editorial Ciencias Médicas, 2013. ISBN: 978-959-212-859-850.

51. Suardiaz Martínez L, León Alvarez JL, Pérez Caballero MD (2013) Monitoreo Ambulatorio de la Presión Arterial. Manual de Prácticas Médicas H.C.Q. "Hermanos Ameijeiras" IV Edición. Editores científicos: Héctor Rodríguez Silva, José Antonio Negrin Villavicencio (Ed), La Habana: Editorial Ciencias Médicas, ISBN: 978-959-212861-863. 
52. Scheppach JB, Raff U, Toncar S, Ritter C, Klink T et al (2018). Blood Pressure Pattern and Target Organ Damage in Patients With Chronic Kidney Disease. Hypertension 72(4):929-936.

53. Mena LJ, Felix VG, Melgarejo JD, Maestre GE (2017) 24-Hour Blood Pressure Variability Assessed by Average Real Variability: A Systematic Review and Meta-Analysis. J Am Heart Assoc. 19;6(10).

54. Kario K, Kanegae H, Tomitani N, Okawara Y, Fujiwara T et al (2019). Nighttime Blood Pressure Measured by Home Blood Pressure Monitoring as an Independent Predictor of Cardiovascular Events in General Practice. Hypertension.73(6):1240-1248.

55. Hinderliter AL, Routledge FS, Blumenthal JA, Koch G, Hussey MA,et al (2013). Reproducibility of blood pressure dipping: relation to day-to-day variability in sleep quality. J Am Soc Hypertens.; 7(6):432-439.

56. Bowles NP, Thosar SS, Herzig MX, Shea SA (2018) Chronotherapy for hypertension. Curr Hypertens Rep. 28;20(11):97.

57. Portaluppi F, Tiseo R, Smolensky MH, Hermida RC, Ayala DE, et al (2012) Circadian rhythms and cardiovascular health. Sleep Med Rev. 16(2):151-166.

58. Palatini P, Reboldi G, Beilin LJ, Casiglia E, Eguchi K, et al (2014) Added predictive value of night-time blood pressure variability for cardiovascular events and mortality: the Ambulatory Blood Pressure-International Study. Hypertension. 64:487-493.

59. Leoncini G, Viazzi F, Storace G, Deferrari G, Pontremoli R (2013) Blood pressure variability and multiple organ damage in primary hypertension. J Hum Hypertens. 27:663-670.

60. Cuspidi C, Meani S, Valerio C, Sala C, Fusi Vet al (2007). Reproducibility of dipping/nondipping pattern in untreated essential hypertensive patients: impact of sex and age. Blood Press Monit. 12(2). 35.

61. Hermida RC, Ayala DE, Fernández JR, Calvo C (2008) Chronotherapy improves blood pressure control and reverts the nondipper pattern in patients with resistant hypertension. Hypertension. 51(1):6976.

62. Zornosa J, Smith M, Little W (1992) Effect of activity on circadian variation in time of onset of acute myocardial infarction. Am J Cardiol. 15; 69(12):1089-1090.

63. Boggia J, Li Y, Thijs L, Hansen TW, Kikuya M et al. (2007) Prognostic accuracy of day versus night ambulatory blood pressure: a cohort study. Lancet. 6; 370(9594):1219-1229.

64. Sobiczewski W, Wirtwein M, Gruchała M, Kocić I. (2014) Mortality in hypertensive patients with coronary heart disease depends on chronopharmacotherapy and dipping status. Pharmacol Rep. 66(3):448-452.

65. Kaplan NM .(2003) Morning surge in blood pressure. Circulation. $18 ; 107(10): 1347$.

66. Salles GF, Reboldi G, Fagard RH, Cardoso CR, Pierdomenico SD et al. (2016) Prognostic Effect of the Nocturnal Blood Pressure Fall in Hypertensive Patients The Ambulatory Blood Pressure Collaboration in Patients With Hypertension (ABC-H) Meta-Analysis. Hypertension. 67(4):693-700.

67. Staessen JA, Thijs L, Fagard R, O'Brien ET, Clement D et al. (1999) Predicting cardiovascular risk using conventional vs ambulatory blood pressure in older patients with systolic hypertension. Systolic Hypertension in Europe Trial Investigators. JAMA. 11;282(6):539546.

68. Gallerani M, Manfredini R, Ricci L, Cocurullo A, Goldoni C et al. (1993) Chronobiological aspects of acute cerebrovascular diseases. Acta Neurol Scand. 87(6):482-487.

69. Brandes RP (2014) Endothelial Dysfunction and Hypertension. Hypertension. 64(5):924-928.
70. Wang ZV. Scherer PE. (2008) Adiponectin, cardiovascular function and hypertension. Hypertension. 51(1):8-14.

71. Rizvi AA (2010) Hypertension, obesity and inflammation: the complex designs of a deadly trio. Metab Syndr Relat Disord. 8(4):287294.

72. Mateos-Cáceres PJ, Zamorano-León JJ, Rodríguez-Sierra P, Macaya C, López-Farré AJ (2012) New and Old Mechanisms Associated with Hypertension in the Elderly. Int J Hypertens. 150107.

73. Martins I.J. (2014) Induction of NAFLD with Increased Risk of Obesity and Chronic Diseases in Developed Countries. Open Journal of Endocrine and Metabolic Diseases. 4: 90-110.

74. Martins I.J. (2016) Anti-Aging Genes Improve Appetite Regulation and Reverse Cell Senescence and Apoptosis in Global Populations. Advances in Aging Research, 5: 9-26.

75. Martins I.J.( 2018) Genomic medicine and acute cardiovascular disease progression in diabetes. Res Chron Dis. 2(1): 001-003.

76. Caliskan M, Caliskan Z, Gullu H, Keles N, Bulur S et al. ( 2014) Increased morning blood pressure surge and coronary microvascular dysfunction in patient with early stage hypertension. J Am Soc Hypertens. 8(9):652-659.

77. Cohen DL, Townsend RR. (2014) Is it morning blood pressure surge or extreme nocturnal dipping that accounts for the increased stroke risk in the morning waking hours? J Clin Hypertens (Greenwich). 16(12):847.

78. Fagard RH. (2009) Dipping pattern of nocturnal blood pressure in patients with hypertension. Expert Rev Cardiovasc Ther. 7(6):599605.

79. Marler JR, Price TR, Clark GL, Muller JE, Robertson Tet al. (1989) Morning increase in onset of ischemic stroke. Stroke. 20(4):473-476.

80. Chen L, Yang G. (2015) Recent advances in circadian rhythms in cardiovascular system. Front Pharmacol. 1; 6:71.

81. Kario K, Saito I, Kushiro T, Teramukai S, Tomono Y et al. (2016)Morning Home Blood Pressure Is a Strong Predictor of Coronary Artery Disease: The HONEST Study. J Am Coll Cardiol. 5;67(13):1519-1527.

82. Franklin SS, Larson MG, Khan SA, Wong ND, Leip EP. (2001)Does the relation of blood pressure to coronary heart disease risk change with aging? The Framingham heart study. Circulation. 6;103(9):1245-1249.

83. Israel S, Israel A, Ben-Dov IZ, Bursztyn M. (2011) The Morning Blood Pressure Surge and All-Cause Mortality in Patients Referred for Ambulatory Blood Pressure Monitoring. Am J Hypertens. 24(7):796-801.

84. Kario K. (2005) Morning hypertension: A pitfall a current of hypertensive management. JMAJ. 48(5): 234-240.

85. Sheppard JP, Hodgkinson J, Riley R, Martin U, Bayliss S, et al (2015)Prognostic significance of the morning blood pressure surge in clinical practice: a systematic review. Am J Hypertens. 28(1):3041.

86. White WB. (2001) Cardiovascular risk and therapeutic intervention for the early morning surge in blood pressure and heart rate. Blood Press Monit. 6(2):63-72.

87. Wroe SJ, Sandercock P, Bamford J, Dennis M, Slattery J,et al. (1992) Diurnal variation in incidence of stroke: Oxfordshire community stroke project. BMJ. 18;304(6820):155-157.

88. Elliott WJ.( 1998 ) Circadian variation in the timing of stroke onset: a meta-analysis. Stroke. 29(5):992-996.

89. Casetta I, Granieri E, Portaluppi F, Manfredini R. (2002) Circadian variability in hemorrhagic stroke. JAMA. 287(10):1266-1267. 
90. Hoshide S, Yano Y, Haimoto H, Yamagiwa K, Uchiba K, et al. (2016) Morning and Evening Home Blood Pressure and Risks of Incident Stroke and Coronary Artery Disease in the Japanese General Practice Population The Japan Morning Surge-Home Blood Pressure Study. Hypertension. 68(1):54-61.

91. Kawauchi D, Hoshide S, Kario K.( 2018) Morning Home Blood Pressure and Cardiovascular Events in a Japanese General Practice Population Over 80 Years Old: The J-HOP Study. Am J Hypertens. 15;31(11):1190-1196.

92. Hermida RC, Crespo JJ, Domínguez-Sardiña M, Otero A, Moyá A et al. (2019)Bedtime hypertension treatment improves cardiovascular risk reduction: the Hygia Chronotherapy Trial. Eur Heart J. 22. pii: ehz754.

93. Hoshide S, Yano Y, Mizuno H, Kanegae H, Kario K.( 2018) Dayby-Day Variability of Home Blood Pressure and Incident Cardiovascular Disease in Clinical Practice: The J-HOP Study (Japan Morning Surge-Home Blood Pressure). Hypertension. 71(1):177-184.

94. Goyal D, Macfadyen RJ, Watson RD, Lip GY. (2005)Ambulatory blood pressure monitoring in heart failure: a systematic review. Eur J Heart Fail. 2;7(2):149-156.

95. Ben-Dov IZ, Kark JD, Ben-Ishay D, Mekler J, Ben-Arie L, et al. (2007) Predictors of all-cause mortality in clinical ambulatory monitoring: unique aspects of blood pressure during sleep. Hypertension. 49(6):1235-1241.
96. Culić V. (2014) Chronobiological rhythms of acute cardiovascular events and underlying mechanisms. Int J Cardiol. 15;174(2):417419.

97. Ohkubo T, Imai Y, Tsuji I, Nagai K, Kato J et al. (1998) Home blood pressure measurement has a stronger predictive power for mortality than does screening blood pressure measurement: a population-based observation in Ohasama, Japan. J Hypertens. 16(7):971-975.

98. Kikuya M, Ohkubo T, Asayama K, Metoki H, Obara T et al. (2005) Ambulatory blood pressure and 10-year risk of cardiovascular and non-cardiovascular mortality: the Ohasama study. Hypertension. 45(2):240-245.

99. Verdecchia P, Angeli F, Mazzotta G, Garofoli M, Ramundo E et al. (2012) Day-night dip and early-morning surge in blood pressure in hypertension: prognostic implications. Hypertension. 60(1):34-42.

100. Li Y, Thijs L, Hansen TW, Kikuya M, Boggia J, Richart T, et al. (2010) Prognostic value of the morning blood pressure surge in 5645 subjects from 8 populations. Hypertension. 55(4):1040-1048.I

101. Cuspidi C, Sala C, Valerio C, Negri F, Mancia G. (2012) Nocturnal hypertension and organ damage in dippers and nondippers. Am J Hypertens. 25(8):869-875.

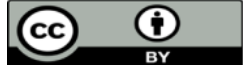

This work is licensed under Creative Commons Attribution 4.0 License

To Submit Your Article Click Here: Submit Article

DOI: $10.31579 / 2641-0419 / 039$
Ready to submit your research? Choose Auctores and benefit from:

* fast, convenient online submission

* rigorous peer review by experienced research in your field

* rapid publication on acceptance

* authors retain copyrights

* unique DOI for all articles

* immediate, unrestricted online access

At Auctores, research is always in progress.

Learn more www.auctoresonline.org/journals/clinical-cardiology-and-cardiovascular-interventions 